\title{
Optimization of the Role of Social Worker Service Units in Legal Protection Effort against Children in Contact with the Law
}

Ummi Rahmatinnur ${ }^{*}$

${ }^{1}$ Faculty of Law, University of Lampung, Lampung, Indonesia

DOI: $10.36348 /$ sijlcj.2022.v05i01.002 $\quad$ | Received: 16.12 .2021 | Accepted: 18.01 .2022 | Published: 21.01 .2022

*Corresponding author: Ummi Rahmatinnur

Faculty of Law, University of Lampung, Lampung, Indonesia

\section{Abstract}

The Social Work Service Unit or often referred to as the social worker service unit is the implementation of the Child Social Welfare Program which was established in 2009 through the Decree of the Minister of Social Affairs of the Republic of Indonesia Number 11A/HUK/2009 concerning the Social Work Service Unit. Sakti social workers are graduates of the DIV/S1 program majoring in social work or social welfare who are selected, educated and appointed as social workers with full employment contract status and serve as assistants for children's social welfare programs at child social welfare institutions, social services or communities that have been determined. One of the main tasks of social workers is to provide assistance to children who are in conflict with the law. The problem that will be described in this study is to analyze the optimization of the role of social worker service units in legal protection efforts for children who are in conflict with the law. This study uses an empirical and normative juridical approach. By examining legal regulations which are then combined with data and behavior that live in the midst of society and go directly to the field of research objects, observations and interviews with respondents who have a close relationship with the research. The results of the research show that the role of the social worker service unit in assisting children in conflict with the law does not run optimally, there are still many children who are in conflict with the law without assistance from social workers. The obstacles faced by social workers in their role as assistants for children who are in conflict with the law are the limited number of social workers, the scientific and scientific background of social workers who are not supportive, the network of cooperation between one institution and another is not good and the time for the implementation of assistance is sometimes difficult. Not according to plan. Optimizing the role of social workers in assisting children in conflict with the law is to increase cooperation with local governments so that they can coordinate or form a forum that can unite law enforcement officers or related parties. The role of social workers is increasingly being expanded. Strict implementation of the code of ethics for social workers by the Social Service.

Keywords: Optimization, Social Work Unit, Children in Conflict with the Law.

Copyright (C) 2022 The Author(s): This is an open-access article distributed under the terms of the Creative Commons Attribution 4.0 International License (CC BY-NC 4.0) which permits unrestricted use, distribution, and reproduction in any medium for non-commercial use provided the original author and source are credited.

\section{INTRODUCTION}

Children are a trust and gift from God Almighty which attaches value and dignity as a whole human being (CST. Kansil: 2004). Children are buds, future potentials and also as the next generation of the ideals and struggles of the nation that have a strategic role and have special characteristics and characteristics that ensure the continuity of the existence of the nation and state.

Every child has the same rights, the right to live, the right to grow and develop to the fullest according to their potential. In the period of growth, children have the need to relate, play with peers, receive education, consume nutritious food and drinks and the most important thing is protection and shelter.

Starting from the circle of family and relatives, the surrounding community, local government to the central government, to the international community are obliged to respect, protect and strive for the fulfillment of children's rights (Farid Zainal Abidin: 2007). If each layer of the task holder can function properly and be able to carry out their obligations and responsibilities, then the child will be able to have a quality life and allow him to grow and develop optimally according to his potential. 
The definition of a child based on Article 1 paragraph (1) of Law Number 23 of 2002 concerning Child Protection is someone who is not yet 18 (eighteen) years old, including children who are still in the womb. The welfare and protection of children in Indonesia has been regulated by various policies and programs, including the 1945 Constitution, where neglected and needy children are cared for by the state. Law of the Republic of Indonesia Number 4 of 1979 concerning Child Welfare has regulated the rights of children, the basic rights of children have not been fulfilled such as civil rights, fundamental freedoms, health, nutrition, water and environmental sanitation, and education (Harahap M. Yahya: 2002).

The distribution of children's problems does not only lead to poverty which effectively contributes to child neglect. The Pusdatin of the Ministry of Social Affairs recorded the number of child problems, including street children in 2019 as many as 230,000 people. This was continued by estimates by BPS and ILO in 2019, as many as 320,000 street children, while the problem of neglected children under five in 2019 was recorded at 21,217,500. child. Neglected children In 2019, 3.1 million children. Other problems, such as delinquency, are increasingly troubling the community, especially in the highly varied forms of delinquency, such as violence that causes fatalities, carried out alone or in groups (Keraf Sonny: 1998).

Another factual condition is children with disabilities. According to data from the Directorate of Social Rehabilitation for Persons with Disabilities, the Ministry of Social Affairs in 2019 in 24 provinces there were 199,263 children with disabilities. Consisting of 78,412 children with mild disabilities, 74,603 children with moderate disabilities and 46,148 children with severe disabilities. Most of the children with disabilities are in poor families, their nutritional needs are not met, they do not receive special care and treatment according to their disabilities from the family. It is estimated that there are many problems with children who are prone to exploitation, economics, and sexuality, although those that appear on the surface are smaller, not to mention children in emergency situations of natural disasters due to the high frequency of natural disasters, and children in conflict situations are no less important to pay attention to (LJ. Van Apeldoorn: 1993).

The social problems of children in Indonesia today are increasingly widespread and complex. There are children's social problems caused by a system that is not well targeted and also because it is intentionally carried out by certain elements Abdul Manan: 2005). The problems that exist include neglected children under five, neglected children, children who are victims of violence or are mistreated, naughty children, street children and children who have problems with the law and others. The Ministry of Women's Empowerment and Child Protection noted that there were at least 4116 cases of violence against children in 2020. This number includes various types of violence against children such as psychological violence, exploitation, sexual abuse, trafficking in persons, discrimination and neglect. The state has an obligation to fulfill, protect and respect children's rights.

In the juvenile criminal justice process, the protection of children who are in conflict with the law, whether perpetrators, witnesses or victims, is not only accompanied by legal advisors and correctional centers (BAPAS), known as community advisors, but also by professional social workers. A professional social worker according to Article 1 paragraph (14) of Law Number 11 of 2012 concerning the Juvenile Criminal Justice System is someone who works, both in government and private institutions, who has the competence and profession of social workers as well as concern in social work obtained through education, training, and practical experience of social workers to carry out service tasks and handling children's social problems.

Social Workers mandated by the Juvenile Criminal Justice System Act, must make optimal efforts to build relationships and coordination with all parties involved in the juvenile justice system. Children need extra loving assistance so that children during the judicial process do not feel afraid. The Directorate of Children of the Ministry of Social Affairs of the Republic of Indonesia has created a program whose target is child welfare through the Child Social Welfare Program which covers all services to children. Children's problems are not limited to the problem of meeting physical, spiritual and social needs, but some children with problems are trapped in difficult situations to get the opportunity to grow and develop properly. Not all children get the opportunity to get enough love, nutrition, health and education to develop and grow healthily because of the condition of the family in poverty and problems, even in an unsafe environment, so that children are neglected and neglected.

Facing the growing problems of children, both in terms of quantity and quality, the Ministry of Social Affairs established a child social welfare program (PKSA) through Presidential Instruction No. 3 of 2010 concerning equitable development aimed at protecting, serving and fulfilling the rights of problem children. Implementation of PKSA assistance to fulfill children's basic needs, accessibility to basic social services, strengthening and developing children's potential and creativity, as well as strengthening family responsibilities, social workers' magic needs to be repositioned starting January 2015.

The Child Social Welfare Program implemented by the Ministry of Social Affairs of the Republic of Indonesia in synergy with the local government, namely the social service and the community, is aimed at directed, integrated and sustainable efforts. Forms of 
Ummi Rahmatinnur., Sch Int J Law Crime Justice, Jan, 2022; 5(1): 8-15

social services to meet children's basic needs include subsidies for basic needs, accessibility of social services, strengthening of parents or families and child social welfare institutions (Maroni: 2012).

The implementation of the Child Social Welfare Program is carried out by a social worker service unit or often also referred to as a social worker. Sakti Peksos was formed in 2009 through the Decree of the Minister of Social Affairs of the Republic of Indonesia Number 11A/HUK/2009 concerning the Social Work Service Unit. Sakti social workers are graduates of the DIV/S1 program majoring in social work or social welfare who are selected, educated and appointed as social workers with full employment contract status and serve as assistants for children's social welfare programs at child social welfare institutions, social services or communities that have been determined.

The aim is to overcome various problems of children and families and utilize various sources, both at the individual, family, institutional, and community levels. In acting as a social worker, social worker is an agent of change who is also involved in helping to solve problems faced by children (Meuwissen: 2007).

The role of social workers in handling children in conflict with the law is very much needed. One of the Child Social Welfare Programs focuses on the protection of children in conflict with the law called the Child Social Welfare Program against the Law. The priority is children who are in conflict with the law who come from pre-prosperous families (Sudikno Mertokusumo: 1987). The Lampung Police General Criminal Investigation Directorate noted that in Lampung Province the number of cases of children in conflict with the law based on data on the number of handling children as victims and children as perpetrators of the Lampung Police General Criminal Investigation Directorate in 2020 was very high. According to the records of the General Criminal Investigation Directorate of the Lampung Police, there were as many as 148 children who were in conflict with the law throughout 2020.

Accompanying children who are in conflict with the law is one of the main tasks of social workers. If social workers are unable to fulfill their obligations, they will be subject to sanctions in accordance with the social worker work guidelines. Sanctions for violation of work discipline consist of light disciplinary penalties, moderate disciplinary penalties and severe disciplinary penalties.

The number of social workers in Lampung Province is 26 people spread across districts/cities in Lampung Province. The child social welfare program has been running in Lampung Province since 2009. In Lampung Province, in practice, not all children who are in conflict with the law are accompanied by the social worker. The juvenile criminal justice system differs from the adult criminal justice system in many ways. A fair juvenile criminal justice provides protection for all children in conflict with the law, this is a major milestone in the criminal justice process.

\section{METHOD OF RESEARCH}

Legal/empirical sociological research which includes research on legal identification (unwritten) and research on the effectiveness of law in society/ field research are the methods used in this research which is based on the science of normative law (laws), but not studying the norm system in the rule of law, instead observing how the reactions and interactions that occur when the norm system works in society (Peter Mahmud Marzuki. 2007).

\section{DISCUSSION}

\section{The Role of the Social Work Service Unit in Legal Protection Efforts against Children in Conflict with the Law}

Formulation of the problem, namely how the role of the social worker service unit is in efforts to protect children who are in conflict with the law. Role is defined as a set of behavior that is expected to be owned by people who are domiciled in society. The position in this case is expected to be a certain position in society that may be high. Moderate or low. Position is a container whose contents are certain rights and obligations, while these rights and obligations can be said to be roles. Therefore, someone who has a certain position can be said to be a role accupant. A right is actually an authority to do or not to do, while an obligation is a burden or a duty (Moeljatno: 2006).

Based on an interview with Nikmah Rosidah as an academic at the law faculty of the University of Lampung, she said that children who are in conflict with the law really need to get assistance from people who are more professionally mature. Assistance for children in conflict with the law is regulated in Article 1 paragraph (12) of Law Number 35 of 2014 concerning amendments to Law Number 23 of 2002 concerning Child Protection, which can be carried out by social workers who have professional competence in their fields.

The characteristic of the professionalism of the social worker service unit is its emphasis on three dimensions, namely the framework of knowledge, values and skills, which in education, all three must be developed in a balanced and simultaneous manner. Other professions generally only emphasize two aspects, namely knowledge and practical skills.

The Social Work Service Unit from the beginning has a high commitment to naming values in its educational process, and defines itself as not a profession or discipline that is value-free, but takes part in a clear and explicit value position, such as human dignity, social justice, partiality to those who unlucky (Moh. Mahfud MD: 2011). The Social Work Service Unit calls itself "normative discipline". Social Worker Service Unit is 
Ummi Rahmatinnur., Sch Int J Law Crime Justice, Jan, 2022; 5(1): 8-15

more than just a technical activity. The Social Work Service Unit is outside an environment that is increasingly controlled by the bureaucracy and managers, where accountability to managers is more emphasized than accountability to the public or consumers. The social work environment does not allow for discretion, initiative, creativity, and finding alternatives in accordance with their commitment to values. The emphasis on knowledge, skills and values has implications for the nature of Social Work practice. If knowledge is seen as as important as skill, then understanding is as important as competene.

Social workers see themselves as thinkers and workers, as well as people who must make judgments based on knowledge and experience before acting. In working with children, especially children in conflict with the law, a Social Worker must take professional actions in accordance with the three dimensions above. Knowledge in the sense of a social worker must have an educational background in social work. Values in the sense of social work practice must be based on certain values, namely the code of ethics for social work practices.

According to Shinta Ariska, Head of the Social Rehabilitation Division of the Lampung Province Social Service, the skills of a social worker are influenced by the increasing number of practices (flying hours). The problem of children in conflict with the law above requires the role of social workers in assisting them. Social workers as a companion must place themselves as friends of children and place children as human beings who deserve to be respected and have rights, not only legal protection but also social protection. To fulfill this protection, Social Workers in collaboration with lawyers demand that law enforcement officers be able to deal with children as witnesses as well as possible (Moleong J. Lexy: 2009).

Based on an interview with Etty Meirini as a representative of the Lampung Police PPA Unit, the role of social workers in assisting children in conflict with the law needs to be further optimized where there are still many cases of children dealing with the law without assistance from social workers (Teguh Prsetyo: 2015).

Social workers should make regular visits to children when children have to be present in court. Sakti peksos must be able to make children express their opinions and express themselves freely. Listening to children's opinions about criminal events that they have heard, seen and experienced (Eddy Rifai and Heni Siswanto: 2015). Sakti Pesos must create an atmosphere of discussion that does not make the child more cornered, but should create an atmosphere of discussion in which the child feels that he is ready to reveal all the details of the events he has experienced.
Sakti Pesos as a companion for children who are witnesses/victims of criminal acts must have personal qualities, both originating from their professional competence and those that are fundamentally attached to the quality of their personality. These personal qualities are obtained in addition to through the training process, especially those obtained from practical experience with children. Awareness to build and improve the quality of awareness to build and improve the personal quality of mentors is continuously developed by the facilitators themselves in the context of their professional responsibilities.

The ultimate goal of the mentoring program for children in conflict with the law is to help them make their own decisions. The key for the service to run effectively lies in the ability of Social Workers to analyze and prioritize needs and achieve some balance in carrying out tasks on an ongoing basis.

The treatment of adults and children should be different. Every child who is in conflict with the law has the right to obtain legal or other effective assistance in every stage of the applicable legal remedy, to defend himself, to obtain justice before an objective and impartial juvenile court, as well as a trial conducted with a single judge, a closed trial for public decisions, spoken in public hearings.

Judges, public prosecutors, legal advisors convened without a gown, including community advisors attending court without wearing official clothes, in court children are also examined in the presence of parents, or guardians or foster parents. This aims to avoid the negative effects of the Juvenile Court process and the stigma caused by court decisions, in accordance with the will of the State to protect the entire Indonesian nation, including promoting the general welfare of children and for the sake of maintaining psychological development (R. Sutyo Bakir: 2009).

At the trial stage, the strategic roles of social workers are:

1. Provide assistance to children in court proceedings.

2. Read the report on the results of community research after the indictment is read.

3. Present at the time of examination of the Child Victim and/or Child Witness.

4. Provide assistance to Child Victims and/or Witness Children who are subjected to direct remote examination using audiovisual communication tools.

Based on the description above, it can be analyzed that the role of the social worker service unit in assisting children in conflict with the law does not run optimally and there are even children who are in conflict with the law without assistance from social workers. So it can be seen that the implementation of the Child Social Welfare Program (PKSA) is not running optimally. 
Where social workers must accompany children who are dealing with the law from the beginning of the legal process until the end of the decision of the legal process. Sakti peksos must be able to make children express their opinions and express themselves freely. Listening to children's opinions about criminal events that they have heard, seen and experienced themselves. Sakti Pesos must create an atmosphere of discussion that does not make the child more cornered, but should create an atmosphere of discussion in which the child feels that he is ready to reveal all the details of the events he has experienced and the child feels protected. And referring to the applicable regulations where assistance for children in conflict with the law is regulated in Article 1 paragraph (12) of Law Number 35 of 2014 concerning amendments to Law Number 23 of 2002 concerning Child Protection, social workers who have professional competence in their fields can provide assistance to children in conflict with the law.

\section{Constraints Occur in the Role of Social Work Units in Legal Protection Efforts for Children in Conflict with the Law}

In the process of assisting children in conflict with the law, social workers need to provide social assistance to children in conflict with the law. This is done so that children who are in conflict with the law can provide information about events they have seen and even experienced in court openly, honestly and without being afraid to reveal them. It is necessary for social workers to carry out social advocacy so that children who are in conflict with the law get recovery, especially related to psychological trauma, because it is not uncommon for children who are in conflict with the law to be closed people and do not want to reveal anything that happens to them (Salman Hr Otje: 2010). There are various obstacles in the importance of the sacred role of social workers in assisting children who are in conflict with the law.

The purpose of legal protection is to provide protection for human rights that have been harmed by others and this protection is given to the public so that they can enjoy all the rights granted by law. Legal protection relates to state actions to do something by applying state law exclusively with the aim of providing guarantees of certainty for the rights of a person or group of people.

According to Shinta Ariska, Head of the Social Rehabilitation Division of the Lampung Province Social Service, the most important obstacle for social workers in assisting children in conflict with the law is the inadequate number of social workers who are ready to assist children in conflict with the law. The duties and obligations of social workers are very numerous, not only accompanying children who are dealing with the law, there are still many other tasks that must be completed in a short time (Agus Susanto Nur: 2014).

Meanwhile, according to Etty Meirini as a representative from the Lampung Police PPA Unit, she explained that she often found it difficult to summon social workers and not all Social Services had an adequate number of social workers. Each Regency and City in Lampung Province on average only has one to two powerful social workers. The number of human resources is not commensurate with the workload borne and children in conflict with the law in Lampung Province are quite high. Other inhibiting factors that also greatly affect the course of activities

Mentoring children who are in conflict with the law is from the scientific side or the scientific background of social workers who are not supportive. The educational background of social workers is supposed to be S1 majoring in social welfare science, so the knowledge gained in college is very supportive for his profession as a social worker. The limited number of social workers is related to their inadequate scientific background in carrying out the social work's sacred duties. This results in social workers in terms of assisting children who are in conflict with the law only as a formality for making social reports. The function of the existence of a social report, namely as material for consideration by the judge on a case, is not achieved. In carrying out their duties, social workers require cooperation with various parties (Geme Maria Theresia: 2012). It is necessary to formulate a method for recovering the condition of the child as a witness to the victim.

Number of human resources for social worker service units in Lampung province:

\begin{tabular}{|l|l|l|}
\hline No & County/City & Number of HR \\
\hline 1 & Bandar lampung & 4 \\
\hline 2 & Metro & 2 \\
\hline 3 & Lampung Selatan & 2 \\
\hline 4 & Pesawaran & 2 \\
\hline 5 & Lampung Tengah & 2 \\
\hline 6 & Lampung Utara & 1 \\
\hline 7 & Way kanan & 1 \\
\hline 8 & Tulang Bawang Barat & 1 \\
\hline 9 & Mesuji & 1 \\
\hline 10 & Pesisir Barat & 1 \\
\hline 11 & Liwa & 1 \\
\hline 12 & Tanggamus & 1 \\
\hline 13 & Lampung Timur & 3 \\
\hline 14 & Tulang Bawang & 1 \\
\hline & Amount & 23 \\
\hline
\end{tabular}


Data on children in conflict with the law (ABH) January-July 2021

\begin{tabular}{|c|c|c|c|c|c|c|c|c|c|}
\hline No & Work Unit & \multicolumn{7}{|c|}{ Month } & Amount \\
\hline & & Jan & Feb & Mart & April & Mei & Juni & Juli & \\
\hline 1 & Polda Lampung & 1 & 2 & 3 & 2 & 0 & 1 & 1 & 10 \\
\hline 2 & Polres Lampung Barat & 1 & 0 & 0 & 2 & 1 & 1 & 2 & 7 \\
\hline 3 & Polres Lampung Utara & 2 & 5 & 0 & 11 & 2 & 4 & 0 & 24 \\
\hline 4 & Polres Lampung Tengah & 1 & 2 & 1 & 1 & 0 & 0 & 0 & 5 \\
\hline 5 & Polres Pesawaran & & & & Nihil & & & & \\
\hline 6 & Polres Mesuji & & & & Nihil & & & & \\
\hline 7 & Polres Waykanan & 2 & 4 & 0 & 1 & 1 & 0 & 0 & 8 \\
\hline 8 & Polres Lampung Timur & 11 & 1 & 1 & 1 & 8 & 0 & 0 & 22 \\
\hline 9 & Polresta Bandar Lampung & & & & Nihil & & & & \\
\hline 10 & Polres Lampung Selatan & 1 & 6 & 0 & 2 & 2 & 2 & 0 & 13 \\
\hline 11 & Polres Metro & & & & & & & & \\
\hline 12 & Polres Tulang Bawang & 0 & 0 & 0 & 4 & 0 & 1 & 1 & 6 \\
\hline 13 & Polres Tulang Bawang Barat & 0 & 0 & 0 & 2 & 0 & 2 & 0 & 4 \\
\hline 14 & Polres Tanggamus & 3 & 0 & 0 & 0 & 0 & 0 & 0 & 3 \\
\hline 15 & Polres Pringsewu & 0 & 0 & 1 & 1 & 0 & 0 & 0 & 2 \\
\hline & Amount & & & & & & & & 104 \\
\hline
\end{tabular}

Furthermore, based on the results of an interview with Tiorisma Sinurat as a social worker at the Social Service Office of Lampung Province, she explained that the timing of the implementation of mentoring was sometimes not according to plan, this was because suddenly there was a sudden task that had to be carried out on the spot so that the implementation of the mentoring had to be delayed. Considering the duties and obligations of social workers, social workers are not only accompanied by those who are in conflict with the law. The limited number of companions does not match the quantity of tasks that must be done (sarifuddin Hidayat at.all: 2017). Related to this is the limited time a social worker has in assisting children in conflict with the law. The next obstacle is in carrying out their duties, the institution does not yet have a shelter for children, so they must find a referral place for children.

Sakti Social Workers feels that the assistance and handling of cases is not in-depth, meaning that the cases handled are not complete, only to the skin of the problem, because there are quite a number of problems that must be accompanied. For example, when one day the social worker magician was conducting an assessment of 4 street children who were arrested by the Bandar Lampung City Satpol PP received a call from the daycare center to immediately resolve the case of another child who had problems at the orphanage. In many cases, there is no complete resolution, only one task is completed, the other must be completed so that it lacks quality and lacks focus in dealing with each case. The results cannot be fully completed, for example the case of street children who are still in a condition where the assessment has to be postponed, the social worker has to do other tasks.

Nikmah Rosidah as an academic at the Faculty of Law, University of Lampung also said that the network of cooperation between social workers and related parties was not much, making it difficult for the mentoring process to run smoothly, this is an obstacle for social workers in carrying out assistance for children who are in conflict with the law. Cooperation networks can be carried out with all relevant parties who can support the purpose of implementing assistance to children who are in conflict with the law in the criminal justice process.

Based on the description above, it can be analyzed that the obstacles faced by social workers in their role as assistants for children in conflict with the law are the limited number of social workers who are adequate and ready to assist children in conflict with the law in courts in every district and city in Indonesia.

Lampung province. This is not proportional to the number of cases of children dealing with the law and the burden of the special duties of the Pekos which are too many in other fields. The scientific and scientific background of the social workers who do not support. The network of cooperation between one institution and another is not good, making it difficult for the facilitation process to be smooth. The timing of the implementation of the mentoring is sometimes not according to the plan, this is because suddenly there is a sudden task that must be carried out at that time so that the implementation of the mentoring has to be delayed. In carrying out its duties, the institution does not yet have a shelter for children, so it must find a referral place for children.

\section{Optimizing the role of the Social Work Service Unit in Legal Protection Efforts for Children in Conflict with the Law}

The results of the study show that more than half of child court cases that are in conflict with the law are not accompanied by social workers and it can be 
Ummi Rahmatinnur., Sch Int J Law Crime Justice, Jan, 2022; 5(1): 8-15

said that the assistance of children by social workers is quite low. Collaborating on mentoring tasks from parents/guardians or people trusted by children, community advisors, advocates or other legal aid providers, professional social workers and social welfare workers. Specifically for assistance to social workers, at each level of examination, children must be accompanied by social workers in accordance with the provisions of the legislation. The targets in the activities carried out by the government reach the Attorney General's Office, the Police, the Ministry of Social Affairs, the Supreme Court, and the Ministry of Law and Human Rights (M. Wantu Fence: 2012).

The government's goal is to create a common perception regarding the handling of problematic children with the law. Social workers must be able to carry out the recovery and reintegration of children as victims' witnesses. Recovery can be done by preparing various victims' recovery facilities, such as hospitals and health centers as crisis centers, shelters, trauma centers and rehabilitation centers, as well as integrated service centers in the regions. Then develop various standards and systems for recovery and integration, complaints, and compensation for victims' losses. Develop alternative education for victims and allocate central and local government budgets for recovery and reintegration for victims.

Progressive law enforcement theory is used to answer this third problem, namely how to optimize the role of social worker service units in legal protection efforts for children who are in conflict with the law. Progressive law is law that has a strong character and has a correlation with responsive law, which looks at the process of involving community participation and progressive law sees how law enforcers perceive the law.

Based on the results of an interview with Mrs. Shinta Ariska as the head of the social rehabilitation division of the Lampung province social service, in order to overcome the obstacles experienced by social workers, various efforts can be made to optimize the role of social workers in assisting children who are in conflict with the law. The local government through the Social Service can coordinate or form a forum that can unite law enforcement officers or related parties so that all parties can be well in accordance with the mandate of the Child Criminal Justice System Law Number 11 of 2012 .

Not only that, the local government is expected to be able to make an inventory of social workers who are ready to assist children in conflict with the law and also social institutions that have job training programs. This greatly facilitates law enforcement officers in determining follow-up actions for children in conflict with the law. The imposition of a discipline violation on social workers' work attendance discipline is given by the social worker social work professional supervisor team after considering and verifying the report of the LKSA leader or agency head or Social Service or input from parties related to social worker work attendance discipline violations with the following types:

1. Light disciplinary punishment is given if the social worker cannot carry out his obligations for three consecutive days or five days cumulatively in one month without any valid information.

2. Disciplinary punishment is being given if social workers cannot carry out their obligations for 20 days cumulatively during the contract period without valid information.

3. Severe disciplinary punishment is given if the social worker cannot carry out his obligations more than 20 working days, based on the police report having committed a criminal act which can be subject to legal sanctions by the authorities.

Furthermore, based on the results of an interview with Nikmah Rosidah as an academic at the Law Faculty of the University of Lampung, conveyed that the role of social workers needed to be further expanded. It is hoped that there will be socialization from the competent institution to all levels of society regarding the child social welfare program (PKSA) of the social ministry of the republic of Indonesia which is carried out by the social worker service unit (Sakti peksos).

Sakti Social Workers must carry out their obligations in accordance with applicable provisions which in this case are contained in the Child Protection Act where assistance for children in conflict with the law is regulated in Article 1 paragraph (12) of Law Number 35 of 2014 concerning amendments to Law Number 23 of 2002 concerning Child protection can be carried out by social workers who have professional competence in their fields and in accordance with the guidelines of the child protection social worker service unit (sakti peksos PA) which contains the rights and obligations of social workers and the manual for social workers. If the social worker does not carry out its obligations, it is hoped that the Social Service Office will take firm action in accordance with existing regulations.

According to Etty Meyrini, in the trial process, the judge in conducting a trial by presenting children must consider the results of social reports from social workers. The social report will then always be used in each stage of the trial. The report will later be used as the basis for further research to design a child development program. For this reason, it is necessary to encourage the improvement of resources, infrastructure and strengthening the capacity of the apparatus related to assisting children who are in conflict with the law, namely social workers. And the most important thing is that all interested parties must monitor judicial practice in order to optimize the position of social workers. 
Ummi Rahmatinnur., Sch Int J Law Crime Justice, Jan, 2022; 5(1): 8-15

If observed, the Juvenile Court Law is more focused on assisting parents in child trials, this is what then raises the understanding that the existence of social workers depends on their availability, so they are alternative, if the child is already accompanied by his parents, then social workers are not required. If the Child Social Welfare Program cannot run properly so that the objectives of the program are not achieved, the government can carry out an evaluation of the program through the Ministry of Social Affairs of the Republic of Indonesia.

Based on the description above, it can be seen that the optimization of the role of social workers in assisting children who are in conflict with the law is social social workers and related institutions must improve cooperative relations so that they can coordinate or form a forum that can unite law enforcement officers or related parties with optimal. The role of social workers is increasingly being expanded, there is a need for socialization from authorized institutions to all levels of society regarding the child social welfare program (PKSA) of the social ministry of the republic of Indonesia which is carried out by the social worker service unit (Sakti peksos). Strict implementation of the code of ethics for social workers by the social service agency

\section{CONCLUSION}

The role of the social worker service unit in assisting children Those dealing with the law are social workers who must be able to make children express their opinions and express themselves freely. Listening to children's opinions about criminal events that they have heard, seen and experienced themselves. Sakti Pesos must create an atmosphere of discussion that does not make the child more cornered, but should create an atmosphere of discussion in which the child feels that he is ready to reveal all the details of the events he has experienced and the child feels protected.

The obstacle faced by social workers in their role as assistants for children who are in conflict with the law is the limited number of social workers who are adequate and ready to assist witnesses in court proceedings in every district and city in Lampung Province. The scientific and scientific background of the social workers who do not support. The network of cooperation between one institution and another is not good, making it difficult for the facilitation process to be smooth. The timing of the implementation of the mentoring is sometimes not according to the plan, this is because suddenly there is a sudden task that must be carried out at that time so that the implementation of the mentoring has to be delayed. In carrying out its duties, the institution does not yet have a shelter for children, so it must find a referral place for children.
Optimizing the role of social workers in assisting children in conflict with the law is to increase cooperation with local governments so that they can coordinate or form a forum that can unite law enforcement officers or related parties. The role of social workers is increasingly being expanded. Strict implementation of the code of ethics for social workers by the social service.

\section{REFERENCES}

- Agus Susanto, N. (2014). Axiological Dimensions of the Decision of the Case "ST" Review of Decision on Review Number 97 PK/Pid.Sus/2012. Judicial Journal, 7.

- $\quad$ Kansil, C. S. T., \& Christine, S. T. K. (2004). Principles of Criminal Law, Jakarta: Pradanaya Paramita.

- Farid, Z. A. (2007). Criminal Law 1, Jakarta: Sinar Graphics.

- Geme, M. T. (2012). Legal Protection of Indigenous Law Communities in the Management of the Watu Ata Nature Reserve, Ngada Regency, East Nusa Tenggara Province, Dissertation, Doctoral Program in Law, Universitas Brawijaya Malang.

- Harahap, M. Y. (2002). Discussion of Problems and Application of the Criminal Code for Investigation and Prosecution, Jakarta: Sinar Graphic.

- Keraf, S. (1998). Business Ethics Guidance and Its Relevance, Yogyakarta: Kanisius.

- Van Apeldoorn, L. J. (1993). Introduction to Law, trans. Oetarid Sadino, Jakarta: Pradnya Paramita.

- Manan, A. (2005). Application of Civil Procedure Law in Religious Courts, Jakarta: Kencana.

- Maroni. (2012). The Face of Law in Reality, Bandar Lampung, University of Lampung.

- Mertokusumo, S. (1987). Legal Protection for the Indonesian people, Surabaya: PT. Build Knowledge.

- Meuwissen. (2007). Concerning the Development of Law, Legal Studies, Legal Theory and Philosophy of Law, translated by Arief Sidharta, Bandung: PT Refika Aditama.

- Moeljatno. (2006). Principles of Criminal Law, Jakarta: Rineka Cipta.

- Moh, M., \& Satjipto, R. (2011). Progressive Law Urgency and Criticism of Series of Indonesian Legal Figures, Epistema Institute and HuMa.

- Moleong, J. L. (2009). Qualitative Research Methodology, Bandung: PT. Youth Rosda Karya.

- Prasetyo, T. (2015). Dignified Justice, Bandung: Nusa Media.

- Sutyo, B. R. (2009). Complete Indonesian Dictionary, Tangerang: Karisma Publishing Group.

- Rifai, E., \& Heni, S. (2015). Law and Law Enforcement, Bandar Lampung: Justice Publisher.

- Salman, H. R. O. (2010). Philosophy of Law (Development \& Dynamics of Problems), Bandung: PT. Refika Aditama.

- Syarifuddin, H., \& Ahmad, M. (2017, August). Legal Protection for Children Victims of Exploitation as Artists, Pulpit of Justice Journal of Legal Studies.

- Wantu, F. M. (2012). Realizing Legal Certainty, Justice and Benefit in Judges' Decisions in Civil Courts. Journal of Legal Dynamics, 12(3). 